\title{
Cerebral abscesses of tuberculosis origin: study of 8 cases at the University Hospital of Conakry
}

\author{
Barry Louncény Fatoumata ${ }^{1,2 *}$, Souare Ibrahima Sory ${ }^{1}$, Cissé Fodé Abass², Djibo Hamani A. Bachir², \\ Atakla H. Ghislain ${ }^{1}$, Condé Alpha Youssouf ${ }^{1}$, Barry Mamoudou ${ }^{2}$, Barry Souleymane Djigué2, Donzo Ansoumane ${ }^{1}$, \\ Barry Ibrahima Sory', Ibrahima Sory Souaré $\mathrm{Jr}^{1}$, Youla Sény ${ }^{2}$, Camara Mamadi and Cissé Amara ${ }^{2}$
}

\begin{abstract}
Introduction: Tuberculosis of the central nervous system (CNS) remains endemic in developing countries with high morbidity and mortality despite advances in imaging and treatment. The objective of our work was to describe the diagnostic and therapeutic difficulties of this pathology in the context of a country with limited health resources.

Materials and methods: We retrospectively studied 8 cerebral tuberculosis abscess files, collected in the archives of the neurosurgery department of the Conakry University Hospital over a 5-year period (January 2013-December 2017). The diagnosis was made by scanning and by isolation of acid-fast bacilli (AFB) by direct examination of pus.

Results: Mean age was 33 years (9-56 years), sex, $5 \mathrm{H} 5$ men/3F 3 women. History of pulmonary TB, 3 cases; TB contagious, 5 cases; TST ITR positive, 5 cases; associated visceral TB, 5 cases; HIV positive serology, 2 cases. The clinic was dominated by altered consciousness, 7 cases; focal signs, 7 cases; and fever, 5 cases. The site was hemispherical in 7 cases and one case in the posterior brain fossa. Treatment was medico-surgical in all patients. The evolution was favorable in 3 cases, the neurological sequelae in 3 cases, 2 cases of death, and 2 cases of recurrence.
\end{abstract}

Conclusion: Cerebral tuberculous abscesses constitute a medico-surgical emergency. Despite their rarity, morbidity and mortality remains high in the context of developing countries due to diagnostic and therapeutic delays.

Keywords: Abscess, Tuberculosis, CNS, Neurosurgery, Conakry

\section{Introduction}

Tuberculosis, caused by Mycobacterium tuberculosis, remains a hot topic around the world. It is a major public health problem in developing countries, where it remains common $[1,2]$. It is on the rise in developed countries, especially since the AIDS pandemic [3]. Cerebral intraparenchymal tuberculosis accounts for $10-30 \%$ of intracranial expansive processes in developing countries [4-6] where it remains endemic and associated with high morbidity and mortality despite advances in imaging and treatment. Despite their low frequency $(1 \%$

\footnotetext{
*Correspondence: drlcbarry@gmail.com

${ }^{1}$ Neurosurgery Department, University Hospital of Conakry, Conakry, Guinea

${ }^{2}$ Neurology Department, University Hospital of Conakry, Conakry, Guinea
}

of extrapulmonary tuberculosis cases) [7], they occupy a special place because of their poor prognosis, mainly due to the delay in treatment. This parenchymal localization is essentially confined to tuberculomas. Abscesses are exceptional [8].

We report our experience in order to describe the diagnostic and therapeutic difficulties of this pathology in the context of a country with limited health resources.

\section{Materials and methods}

We retrospectively studied 8 cerebral tuberculosis abscess files, collected in the archives of the neurosurgery

\section{Springer Open}

(อ) The Author(s). 2020 Open Access This article is licensed under a Creative Commons Attribution 4.0 International License, which permits use, sharing, adaptation, distribution and reproduction in any medium or format, as long as you give appropriate credit to the original author(s) and the source, provide a link to the Creative Commons licence, and indicate if changes were made. The images or other third party material in this article are included in the article's Creative Commons licence, unless indicated otherwise in a credit line to the material. If material is not included in the article's Creative Commons licence and your intended use is not permitted by statutory regulation or exceeds the permitted use, you will need to obtain permission directly from the copyright holder. To view a copy of this licence, visit http://creativecommons.org/licenses/by/4.0/. 
department of the Conakry University Hospital over a 5year period (January 2013-December 2017).

All our patients benefited from a complete clinical examination, a standard check-up (blood count, Creactive protein, HIV serology, tuberculin intradermal reaction, examination of sputum or gastric tubing, and urine for acid-fast bacilli), cerebral CT scan, chest X-ray, and direct examination of pus with Ziehl-Neelsen staining for mycobacteria after puncture of the abscess. All patients received quadruple therapy (isoniazid, rifampicin, ethambutol, and pyrazinamide) for 3 months, combined with corticosteroid therapy for the first 15 days (prednisolone) and then dual therapy (isoniazid and rifampicin) for 18 months. Surgical treatment was carried out in all cases. The operating technique was a freehand evacuating puncture; an excision of the hull was associated in case of recurrence.

The evolution was judged good when there was clinical recovery without sequelae, average when there were neuropsychic or motor sequelae, and poor in case of death.

Our study essentially concerned patients whose direct examination of pus isolated acid-fast bacilli (AFB) in pus. The data collected were analyzed using the SPSS version 21.0 software.

\section{Results}

\section{Epidemiologic characteristics}

The average age of our patients was 33 with extremes of 9 and 56. The study concerned 5 men and 3 women.
Three patients had a history of pulmonary tuberculosis, and the notion of tuberculosis contagion was found in 5 cases. Intradermal tuberculin reaction was positive in 5 cases. Pulmonary tuberculosis was associated in 4 cases and urogenital in 1 case. The HIV serology was positive in 2 cases.

\section{Clinical manifestations}

Clinically, the presentation of symptomatology was variable, dominated by disturbances of consciousness, focal neurological signs, and fever. The general patients' characteristics are summarized in Table 1. The time to diagnosis ranged from 3 weeks to 4 months.

\section{Biological data}

Biology showed hyperleukocytosis in 4 cases and positive CRP in 5 cases. Direct examination of pus isolated numerous acid-fast bacilli (greater than 10/fields) in all cases.

\section{Medical imaging data}

Chest X-rays, performed in all patients, showed abnormalities in 5 patients with a miliary appearance in 2 cases, an active tuberculosis appearance in 2 cases, and stigmas of a tuberculous past in 1 case.

In the brain scan performed in all patients, the image was typical of a cockade of spontaneous hypodensity contrasting in a ring pattern and surrounded by a large hypodense halo of edema. The localization was hemispherical in 7 cases including 4 frontal cases (Fig. 1), 2 temporal cases, 1 multiple case (Fig. 2), and in the

Table 1 General patients' characteristics

\begin{tabular}{|c|c|c|c|c|c|c|c|c|}
\hline & Case no. 1 & Case no. 2 & Case no. 3 & Case no. 4 & Case no. 5 & Case no. 6 & Case no. 7 & Case no. 8 \\
\hline Age/sex & 9 years, male & 37 years, male & $\begin{array}{l}50 \text { years, } \\
\text { female }\end{array}$ & $\begin{array}{l}41 \text { years, } \\
\text { male }\end{array}$ & 24 years, female & 31 years, male & $\begin{array}{l}15 \text { years, } \\
\text { male }\end{array}$ & $\begin{array}{l}59 \text { years, } \\
\text { female }\end{array}$ \\
\hline $\begin{array}{l}\text { History of } \\
\text { tuberculosis }\end{array}$ & Yes & No & No & No & Yes & No & No & Yes \\
\hline $\begin{array}{l}\text { Notion of } \\
\text { contagion }\end{array}$ & Yes & No & Yes & No & Yes & No & Yes & Yes \\
\hline ITR & Positive & Positive & Negative & Positive & Negative & Positive & Positive & Negative \\
\hline $\begin{array}{l}\text { Extracerebral } \\
\text { tuberculosis }\end{array}$ & No & Yes, urogenital & $\begin{array}{l}\text { Yes, } \\
\text { pulmonary }\end{array}$ & $\begin{array}{l}\text { Yes, } \\
\text { pulmonary }\end{array}$ & No & Yes, pulmonary & No & $\begin{array}{l}\text { Yes, } \\
\text { pulmonary }\end{array}$ \\
\hline HIV serology & Negative & Negative & Negative & Negative & Positive & Negative & Negative & Positive \\
\hline Clinic & $\begin{array}{l}\text { Fever, } \\
\text { headache, } \\
\text { vomiting, } \\
\text { confusion }\end{array}$ & $\begin{array}{l}\text { Headache, } \\
\text { vomiting, } \\
\text { slimming, focal } \\
\text { sign, confusion }\end{array}$ & $\begin{array}{l}\text { Fever, } \\
\text { vomiting, } \\
\text { slimming, } \\
\text { focal sign, } \\
\text { coma }\end{array}$ & $\begin{array}{l}\text { Fever, } \\
\text { headache, } \\
\text { focal sign, } \\
\text { confusion }\end{array}$ & $\begin{array}{l}\text { Fever, headache, } \\
\text { vomiting, } \\
\text { slimming, focal } \\
\text { sign, coma }\end{array}$ & $\begin{array}{l}\text { Headache, focal } \\
\text { sign, convulsions, } \\
\text { coma, slimming }\end{array}$ & $\begin{array}{l}\text { Headache, } \\
\text { focal sign, } \\
\text { convulsions }\end{array}$ & $\begin{array}{l}\text { Fever, focal } \\
\text { sign, } \\
\text { convulsions, } \\
\text { coma }\end{array}$ \\
\hline $\begin{array}{l}\text { Antituberculosis } \\
\text { treatment } \\
\text { (duration) }\end{array}$ & 21 months & 21 months & 21 months & 21 months & 2 months & 21 months & 21 months & 1 month \\
\hline Surgery & $\begin{array}{l}\text { Puncture, } \\
\text { exeresis }\end{array}$ & Puncture & Puncture & Puncture & Puncture & Puncture & Puncture & $\begin{array}{l}\text { Puncture, } \\
\text { exeresis }\end{array}$ \\
\hline Evolution & Favorable & Favorable & $\begin{array}{l}\text { Average } \\
\text { (hemiparesis) }\end{array}$ & $\begin{array}{l}\text { Average } \\
\text { (epilepsy) }\end{array}$ & Death & $\begin{array}{l}\text { Average } \\
\text { (epilepsy) }\end{array}$ & Favorable & Death \\
\hline
\end{tabular}


posterior fossa in 1 case (Fig. 3). Hydrocephalus was associated in 1 case and subdural empyema in 1 case (Fig. 4).

\section{Treatment}

The treatment was medico-surgical in all our patients. The medical treatment consisted of quadruple therapy (isoniazid $300 \mathrm{mg} /$ day, rifampicin $600 \mathrm{mg} /$ day, ethambutol $1800 \mathrm{mg} /$ day, and pyrazinamide $1200 \mathrm{mg} /$ day) for 3 months, combined with corticosteroid therapy for the first 15 days (prednisolone $2 \mathrm{mg} / \mathrm{kg} /$ day) then dual therapy (isoniazid and rifampicin) for 18 months.

The time of surgery varied from $24 \mathrm{~h}$ to 2 weeks. For 6 cases, it was performed within the first $24 \mathrm{~h}$ following hospitalization and for 2 cases after failure of 2 weeks of trial treatment (Adiazine ${ }^{\circ} 4 \mathrm{~g} / \mathrm{d}$ Malocide ${ }^{\circ} 1 \mathrm{mg} / \mathrm{kg} / \mathrm{d}$ ) for suspicion of cerebral toxoplasmosis in the field of HIV. It consisted of a trepano-puncture in all patients, which was justified on criteria of size and clinical tolerance, notably for consciousness disorders associated with a compressive collection.

\section{Evolution}

The evolution was favorable in 3 cases, average in 3 cases ( 1 case of hemiparesis and 2 cases of epilepsy), and

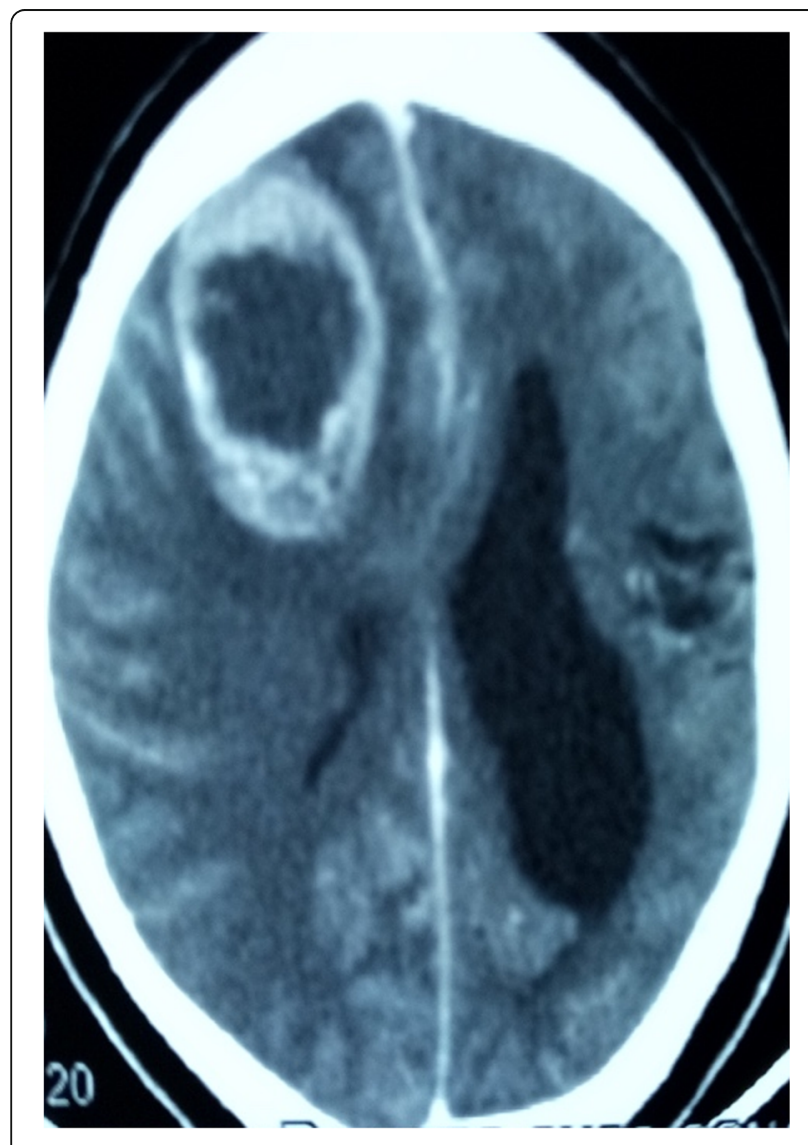

Fig. 1 Frontal abscess

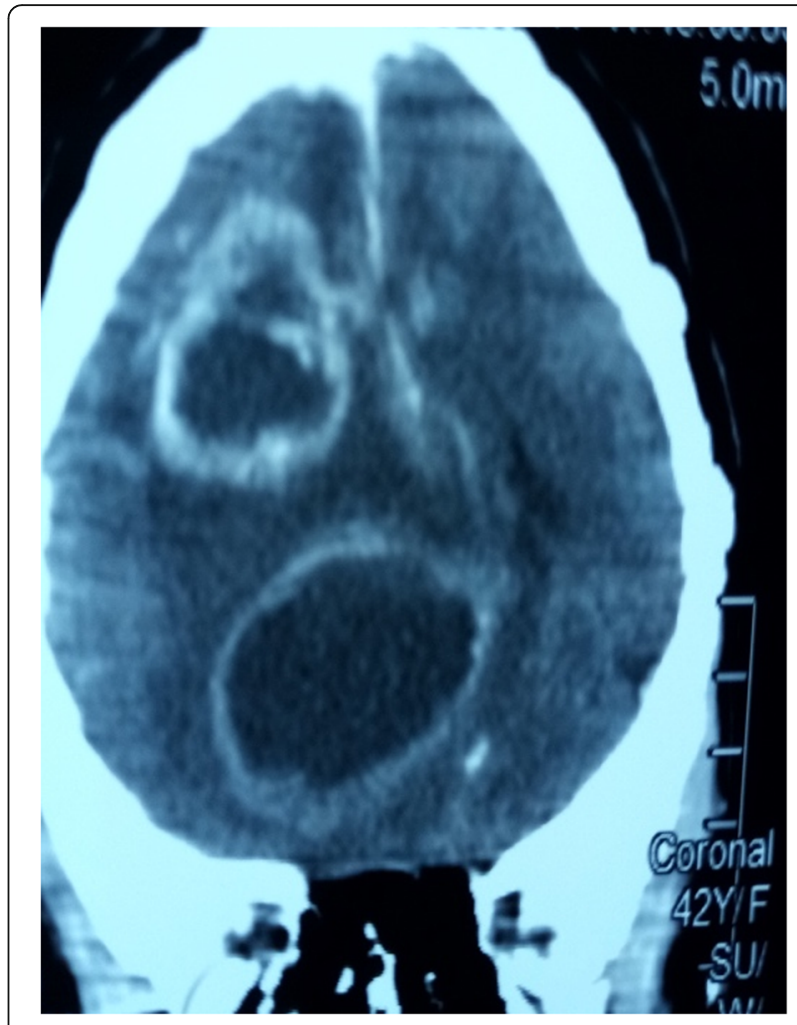

Fig. 2 Multiple abscesses

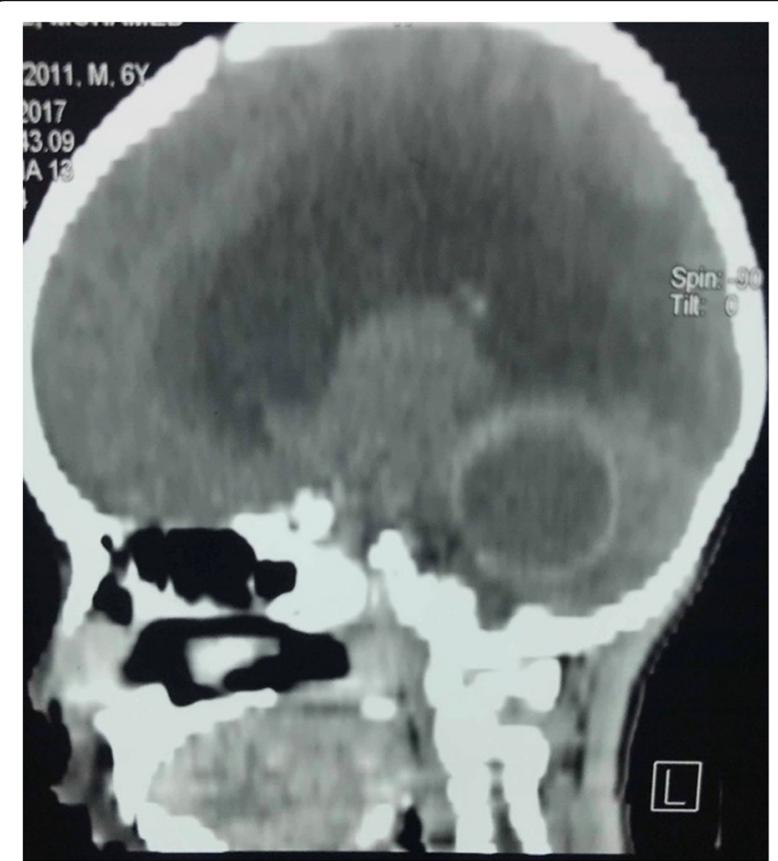

Fig. 3 Cerebellar abscess with overlying hydrocephalus 


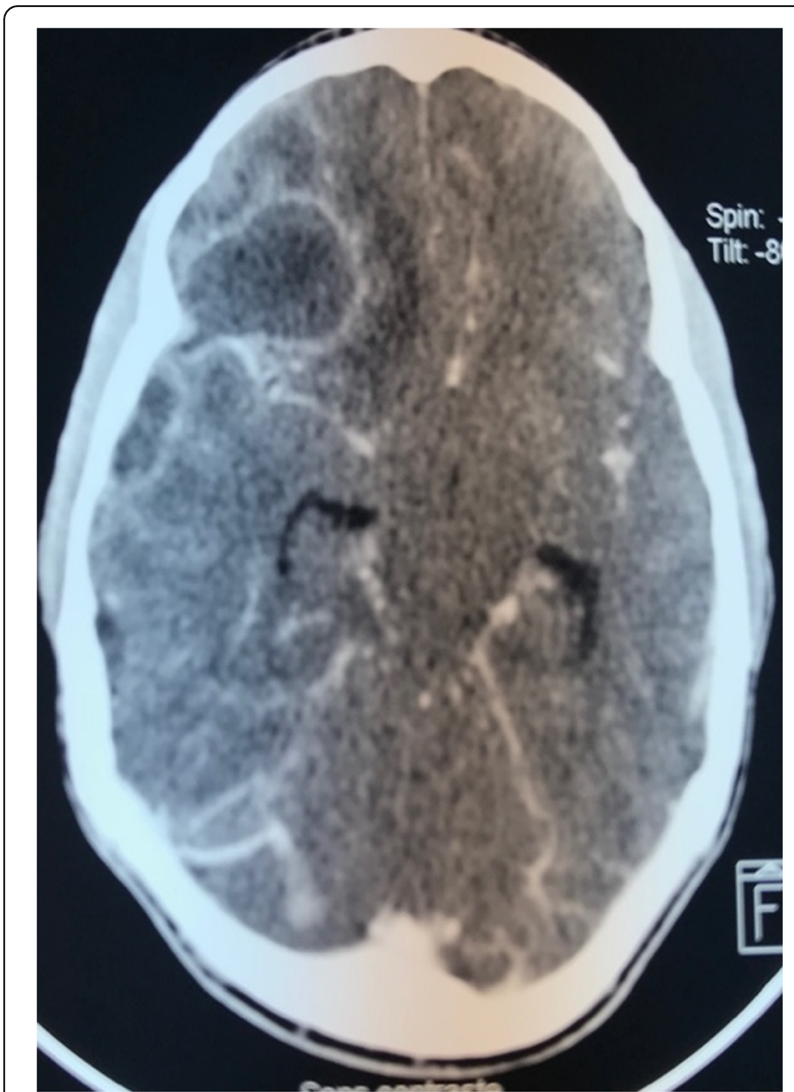

Fig. 4 Frontal abscess associated with empyema

bad in 2 cases ( 2 deaths: 1 case of respiratory distress and 1 case of septic shock). Recurrence was noted in 2 cases, requiring surgical removal.

\section{Discussion}

CNS tuberculosis is common in developing countries. It has been on the rise in industrialized countries since the advent of HIV 1 infection [4]. CNS involvement can take three forms of unequal frequency: tubercular meningitis, tuberculomas, and, exceptionally, tubercular abscesses [9]. Cerebral abscess is a rare lesion in tuberculosis, occurring in $4-8 \%$ of non-HIV patients and $20 \%$ of AIDS patients [10]. The abscess is often single, sometimes multilocular and accompanied by greater perilesional edema [11]. It most often occurs in the corticosubcortical regions and in the central gray nuclei, but also in the cerebellum. Genuine cerebral subdural tuberculous empyema has been more rarely reported [12, 13], encountered in a patient in our series.

These brain abscesses, like tuberculomas, are probably secondary to hematogenous dissemination from a primitive site, most often pulmonary, sometimes acute, contemporary with the abscess [14] as was the case in 4 patients in our series, sometimes old scarring or chronic [15], encountered in 3 patients in our series and 18 patients out of 122 in Kilani et al. series on adult central nervous system tuberculosis [11], and sometimes digestive, lymph node, or urinary [16] as reported in a patient in our series. On the other hand, the low frequency of abscesses compared to tuberculomas remains unexplained. Lecuit et al. hypothesize the role of CD4 deficiency as an etiopathogenic factor in the lower frequency of granulomas, which are controls for the host response to the presence of the pathogen in HIVinfected patients [17].

Unfortunately, the tuberculin intradermal reaction is of limited value: negative, it does not eliminate the diagnosis, given the possibility of anergy; positive, it is not a certainty. Finally, it is rarely phlyctenular. In our series, it was positive in 5 of the cases and only positive in 1 in 7 cases in the series of Mazodier et al. on neuromeningeal tuberculosis [18].

The clinical signs found in the literature are similar to those due to pyogenic abscesses [9, 17]. They include focal deficits in 7 cases in our series, headache in 6 cases in our series, vomiting in 4 cases in our series, fever in 5 cases in our series, convulsions in 3 cases in our series, and altered consciousness in 7 cases in our series. The delayed diagnosis would explain these disorders of consciousness. The patients being admitted most often at a very advanced stage. The localizations are also not very specific. They are more frequent in the supra-tentorial stage 7 cases in our series, rare in the posterior fossa 1 case in our series and sometimes multiple 1 case in our study, or sometimes may be associated with another tubercular disease of the central nervous system [19].

The progress made with the contribution of CT scans has made it possible to differentiate tuberculoma and abscess, but few radiological signs make it possible to separate a tuberculous abscess from a pyogenous abscess. Both lesions have a hypodense center surrounded by a high-contrast crown, and significant peripheral edema. Only a thick annular opacification would suggest a tuberculous origin [20].

In CNS tuberculosis, cerebral CT is still the first-line examination to be performed, especially since it is more easily performed, especially in the following situations of the emergency. MRI, a more sensitive examination, should be reserved when CT lesions are not suggestive or when vascular lesions, brain stem localizations, or associated spinal injury are suspected. However, the high cost of this examination and its unavailability in several centers in our country limit its use [11].

The rarity of this form of tuberculosis can lead to lack of knowledge. In the presence of an expansive cerebral process, whether it appears as an avascular mass or surrounded by a ring of increased vascularity, glial tumors, infarction, tuberculoma, pyogenous, or tuberculous abscess cannot be differentiated during imaging 
investigations with certainty [14]. Tuberculous etiology is evoked if there is also active visceral tuberculosis, encountered 5 times out of 8 times in our series. The presence of epithelioid and gigantocellular follicles is suggestive of a tubercular process but may be totally absent, and other agents may initiate them [14]. That is, without the demonstration of acid-fast bacilli in situ and their isolation in culture, the diagnosis of cerebral tuberculosis can be omitted. Progression under antituberculosis treatment is not discriminatory diagnostic evidence. Indeed, several observations report the development of tuberculous abscesses under well-conducted specific treatment [21, 22]. In our series, diagnostic confirmation was obtained in all cases by isolation of acid-fast bacilli in pus to direct examination after Ziehl-Neelsen coloration, but the culture was not carried out due to the inadequacy of our technical facilities which did not allow sterile pus to be cultured on direct examination, which could explain the relatively low frequency of our series.

The treatment of tuberculous abscesses is medicosurgical, and in all cases it combines a diagnostic and curative surgical procedure with conventional antituberculosis antibiotic therapy [23]. The medical treatment is based on a quadruple therapy combining isoniazid, rifampicin, ethambutol, and pyrazinamide for 2 to 4 months, followed by dual therapy (isoniazid and rifampicin) for 12 to 18 months [24]. Initiated in all patients in our series, it preceded surgical treatment 5 out of 8 cases in patients with visceral tuberculosis. It was associated in all cases in our series with 15 days of corticosteroid therapy which is comparable to the series of Mazodier et al. who combined corticosteroid therapy with antituberculosis treatment in the 7 patients in their study [18]. Corticotherapy would also find its place alongside antituberculosis antibiotics during CNS tuberculosis. One study shows that it reduces mortality and neurological sequelae in patients with a medium severity picture (confusion, focal signs) [18]; other authors show a benefit in severe cases (coma) $[25,26]$. Finally, corticosteroid therapy is believed to reduce the volume of hydrocephalus [26].

Surgically, the treatment of the abscess itself involves two possible techniques: puncture(s)-aspiration(s) with or without stereotactic guidance and excision by craniotomy [9]. The choice of procedure will depend on the general condition of the patient and the size and location of the abscess. In our series, all abscesses were treated by unguided puncture-aspiration using the Cushing's trocar due to the lack of stereotaxis in our technical platform. The direct approach for excision was performed in 2 patients in our series after recurrence.

The evolution of cerebral tuberculous abscess after surgical treatment is often favorable under antituberculosis treatment continued for at least 18 months, initially associated with corticosteroid therapy [9]. The fatal evolution in our series ( 2 cases: 1 case of respiratory distress and 1 case of septic shock) and the sequelae (3 cases: 1 case of hemiparesis and 2 cases of epilepsy) would be related to late surgery due to the delay in diagnosis. In our context, this can be explained by the diagnostic wandering that these patients experience in the upstream structures before their arrival in the referral centers, by the under-equipment of the hospitals, and by the financial difficulties that most of these patients experience.

\section{Conclusion}

Cerebral tuberculous abscesses are a medical-surgical emergency in bulky forms with mass effect. Despite their rarity, morbi-mortality remains high in the context of developing countries because of diagnostic and therapeutic delay. There is no clinical or radiological evidence that points with certainty to the diagnosis of cerebral abscess of tuberculosis origin. It is therefore always necessary to think about it in the face of favorable ground and evocative radiological signs; the diagnosis of certainty is not always easy, and any delay in diagnosis leads to serious sequelae and mortality; the treatment remains medico-surgical.

\section{Acknowledgements \\ Not applicable}

\section{Authors' contributions}

All the authors meet the 4 criteria of the International Committee of Medical Journal Editors (ICMJE): 1. Substantial contributions to research design or methods or to acquisition, analysis, or interpretation of data; 2. Preliminary writing of the article or its critical review involving significant contribution to the intellectual content; 3 . Final approval of the version to be published; 4. Commitment to assume accountability for all aspects of the research by ensuring that the issues related to the accuracy or integrity of any part of the work are examined in a manner that appropriate and resolute.

\section{Funding}

Not applicable

Availability of data and materials Not applicable

\section{Ethics approval and consent to participate}

Our study was exempted from the obligation to obtain ethical approval by the ethical and moral committee of "Ignace Deen" national hospital of Conakry university hospital center (e-mail: mtoty@gmail.com; telephone : 00224628333061).

\section{Consent for publication \\ Not applicable}

\section{Competing interests}

No conflicts of interest

Received: 6 March 2020 Accepted: 23 August 2020

Published online: 03 September 2020

\section{References}

1. De Castro CC, De Barros NG, De Sousa Campos ZM, Cerri GG. CT scans of cranial tuberculosis. Radiol Clin NorthAm. 1995;33:753-69. 
2. Paganini H, Gonzalez F, Santander C, Casimir L, Berberian G, Rosanova MT. Tuberculous meningitis in children: clinical features and outcome in 40 cases. Scand J Infect Dis. 2000;32:41-5.

3. Villoria MF, Fortea F, Moreno S, Munoz L, Manero M, Benito C. MR imaging and $C T$ of central nervous system tuberculosis in the patient with AIDS. Radiol Clin N Am. 1995;33:805-20.

4. Elmamoune A, Souylem MB, Kleib AS, Memou SS, Soumaré O, Salihy SM. Tuberculose cérébrale : à propos de 21 cas. Neurochirurgie. 2019;65:106-44.

5. Mohanti S, Rao CJ. Tuberculous abscess of the brain. Postgrad Med J. 1978; 54:678-9.

6. Rouzaud M, Gouaze A, Degiovanni E. Les formes chirurgicales de la tuberculose cérébrale. A propos de trois observations dont un abcès tuberculeux. Sem Hôpitaux Paris. 1971;47:3063-6.

7. Gavazzi G, Bouchard O, Queyrel V, Bosseray A, Leclercq A, Micoud M. Vascularite et miliaire cérébrale d'origine tuberculeuse: aggravation sous traitement adapté. Rév Med Interne. 1998;19:1

8. Granier H, Robinet G, Guiavarch M, Garo B, Boles JM, Garre M. Abcès multiple d'origine tuberculeusechez un immunodéprimmé. Med Mal Infect. 1991;21:330-1.

9. Mohammedi I, Veber B, Gachot B, Wolff M, Vachon F. Abcès tuberculeux de la fosse postérieure, chez un patient infecté par le VIH. Réan Urg. 1995;4(3): 317-9.

10. Boukobza M, Tamer I, Guichard JP, Brunereau L, Polivka M, Leibinger F, et al. Tuberculose du système nerveux central. Aspects IRM et évolution à propos de 12 cas. J Neuroradiol. 1999;26:172-8.

11. Kilani B, Ammari L, Tiouiri H, Goubontini A, Kanoun F, Zouiten F. Manifestations neuroradiologiques initiales de la tuberculose du système nerveux central de l'adulte. À propos de 122 cas. La Revue de Médecine Interne. 2003;24:86-96.

12. Van Dellen A, Nadri SS, Nathoo N, Ramdial PK. Intracranial tuberculous subdural empyema: case report. Neurosurgery. 1998;43:370-3.

13. Ozates M, Ozkan U, Kemaloglu S, Hosoglu S, Sari I. Spinal subdural tuberculous abscess. Spinal Cord. 2000:38:56-8.

14. Felten-Papaiconomou A, Ruf C, George B. Les abcès du cerveau tuberculeux. A propos de deux cas. Médecine et Maladies Infectieuse. 1981; 1:33-6.

15. Bannister C. A tuberculous brain abscess. Case report. J Neurosurg. 1970;33: 203-6.

16. Withener DR. Tuberculous brain abscess. Report of a case review of the literature. Arch Neurol. 1978;35:148-55.

17. Lecuit M, Rogeaux $\mathrm{O}$, Bricaire $F$, Gentilini M. Tuberculomes intracérébraux au cours de l'infection par le VIH. Épidémiologie et apport de l'IRM. Presse Med. 1994;23:891-5.

18. Mazodier K, Bernit E, Faure V, Rovery C, Gayet S, Seux V, Donnet A, Brouqui P, Disdier P, Schleinitz N, Kaplanski G, Veit V, Harlé J-R. Tuberculose cérébroméningée chez l'adulte séronégatif pour le $\mathrm{VIH}$ : à propos de 7 cas. La Revue de Médecine Interne. 2003;24:78-85.

19. Leblanc R. Tuberculous brain abscess: report of a case with computed tomography correlation. Neurosurgery. 1981;8:88-91.

20. Jinkins JR. Computed tomography of intracranial brain tuberculosis. Neuroradiology. 1991;33:126-35.

21. David M, Benda R, Benda P. foyer confluent encéphalique de nécrose suppurée tuberculeuse : vérification bactériologique per-opératoire. Rev Neurol. 1954;90:854-6.

22. Decuns $P$, Garre $H$, Pascalis $G$. Abcès froids miliaires du cerveau, du cervelet et du tronc cérébral chez un tuberculeux traité par antibiotiques. Rev Otoneuroophtalmol. 1956;28:250-5.

23. Prakash B, Metha G, Gondal R, Kumar S, Malhotra V. Tuberculous abscess of the brain stem. Surg Neurol. 1989;32:445-8.

24. Göksoy E, Düren M, Durgun V, Uygun N. Tuberculosis of the breast. Eur J Surg. 1995;161:471-3.

25. Dooley DP, Carpenter JL, Rademacher S. Adjunctive corticosteroid therapy for tuberculosis: a critical reappraisal of literature. Clin Infect Dis. 1997;25: 872-87.

26. Coyle PK. Glucocorticoids in central nervous system bacterial infection. Arch Neurol. 1999:56:796-801.

\section{Publisher's Note}

Springer Nature remains neutral with regard to jurisdictional claims in published maps and institutional affiliations.

\section{Submit your manuscript to a SpringerOpen ${ }^{\circ}$ journal and benefit from:}

- Convenient online submission

- Rigorous peer review

- Open access: articles freely available online

- High visibility within the field

- Retaining the copyright to your article

Submit your next manuscript at $\boldsymbol{\nabla}$ springeropen.com 